\title{
Photomixotrophism on in vitro elongation of Corymbia hybrid clones
}

\section{Fotomixotrofismo no alongamento in vitro de clones híbridos de Corymbia}

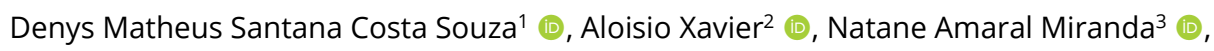 \\ Ricardo Gallo ${ }^{4}$ (D), Gleison Augusto dos Santos ${ }^{2}$ (1) , Brígida Maria dos Reis Teixeira Valente ${ }^{2}$ (1), \\ Wagner Campos Otoni ${ }^{2}$ (1) \\ ${ }^{1}$ Universidade Federal de Lavras - UFLA, Lavras, MG, Brasil \\ ${ }^{2}$ Universidade Federal de Viçosa - UFV, Viçosa, MG, Brasil \\ ${ }^{3}$ Universidade Federal Rural do Rio de Janeiro - UFRRJ, Seropédica, RJ, Brasil \\ ${ }^{4}$ Universidade Federal Rural de Pernambuco - UFRPE, Recife, PE, Brasil
}

How to cite: Souza, D. M. S. C., Xavier, A., Miranda, N. A., Gallo, R., Santos, G. A., Valente, B. M. R. T., \& Otoni, W. C. (2020). Photomixotrophism on in vitro elongation of Corymbia hybrid clones. Scientia Forestalis, 48(128), e3436. https://doi.org/10.18671/scifor.v48n128.11

\begin{abstract}
The importance of Corymbia species and their interspecific hybrids has been evidenced in forestry programs, due to their wood quality and adaptation to various environmental conditions. To solve the in vitro culture limiting factors of a hybrid Corymbia citriodora $\times C$. torelliana and three $C$. torelliana $\times C$. citriodora hybrid clones, the present work aimed to evaluate the influence of photomixotrophism on the in vitro elongation phase. The tissues used to obtain the explants were nodal segments from ministumps of the four hybrid clones. The effect of photomixotrophism was assessed by three light sources (fluorescent lamp, white LEDs and red/blue LEDs); three sucrose concentrations $\left(0,15\right.$ and $\left.30 \mathrm{~g} \mathrm{~L}^{-1}\right)$ and two sealing forms (rigid membrane less polypropylene caps and two membranes). Data on shoot length and number per explant, vigor, shoot oxidation and photosynthetic pigment content were collected at 35 days of in vitro culture. Based on the results obtained, it can be inferred that red/blue LEDs, $15 \mathrm{~g} \mathrm{~L}^{-1}$ sucrose and membrane less vials are more suitable for in vitro elongation of hybrid clones C. citriodora $\times$ C. torelliana and C. torelliana $\times C$. citriodora, without prejudice to the development of shoots intended for the production of micropropagated clonal plants.
\end{abstract}

Keywords: In vitro propagation; Light quality; Gas exchange.

\section{Resumo}

A importância das espécies do gênero Corymbia e de seus híbridos interespecíficos tem sido evidenciada nos programas de silvicultura, devido à sua qualidade da madeira e adaptação a diversas condições de ambiente. Para solucionar os fatores limitantes no cultivo in vitro de um clone híbrido de Corymbia citriodora $\times C$. Torelliana e três de $C$. Torelliana $\times C$. citriodora, o presente trabalho teve como objetivo avaliar a influência do fotomixotrofismo na fase de alongamento in vitro. Os tecidos utilizados para a obtenção dos explantes foram segmentos nodais, provenientes de minicepas dos clones híbridos. O efeito do fotomixotrofismo foi avaliado por meio de três fontes de luz (Lâmpada fluorescente, LEDs branco e LEDs vermelho/azul); três concentrações de sacarose $\left(0,15\right.$ e $\left.30 \mathrm{~g} \mathrm{~L}^{-1}\right)$ e duas formas de vedação (tampas rígidas de polipropileno sem membrana e duas membranas). Dados de comprimento e número de brotos por explante, vigor, oxidação das brotações e conteúdo de pigmentos fotossintéticos, foram coletados aos 35 dias de cultivo in vitro. Com base nos resultados obtidos, pode-se inferir que LEDs vermelho/azul, $15 \mathrm{~g} \mathrm{~L}^{-1}$ de sacarose e frascos sem membrana são mais adequadas para serem utilizadas no alongamento in vitro dos clones híbridos de Corymbia citriodora $\times$ C. Torelliana e C. torellianax C. citriodora, sem prejuízo ao desenvolvimento de brotações destinadas à produção de plantas clonais micropropagadas.

Palavras-chave: Propagação in vitro; Qualidade de luz; Troca gasosa.

Financial support: None.

Conflict of interest: Nothing to declare.

Corresponding author: dmscsouza@gmail.com

Received: 31 July 2019.

Accepted: 4 November 2019

Editor: Paulo Henrique Müller Silva.

(c) This is an Open Access article distributed under the terms of the Creative Commons Attribution License, which permits unrestricted use,

c) distribution, and reproduction in any medium, provided the original work is properly cited. 


\section{INTRODUCTION}

The expansion of forest plantations to non-traditional regions and the search for better adaptation for the production of seedlings have increased the use of species and hybrid combinations. Thus, in recent years, the hybridization of Corymbia citriodora (Hook.) K.D. Hill \& L.A.S. Johnson with Corymbia torelliana (F. Muell.) K.D. Hill \& L.A.S Johnson has provided excellent results, both in terms of wood quality and growth, in addition to better environmental adaptation and easier vegetative propagation (Assis, 2014; Trueman et al., 2018). In this context, alternatives aimed at improving the production process of seedlings in selected hybrid clones of the genus Corymbia, it has been recommended to use of the micropropagation technique via proliferation of axillary buds (Wendling et al., 2014).

Among the stages of micropropagation, the in vitro elongation phase is essential for obtaining shoots for the rooting of the microcuttings, which has been carried out both in the ex vitro (Wendling et al., 2014) and in vitro (Trueman et al., 2018). In recent years, research on the genus Corymbia has increased significantly in relation to vegetative propagation in vitro, aiming to obtain microstumps (Wendling et al., 2014; Brondani et al., 2018; Souza et al., 2018).

In this context, in order to solve the limiting factors of micropropagation, the need is evident for basic studies to improve the production of microstumps in vitro. Biotechnological techniques are being applied in order to automate the micropropagation process, including photomyxotrophism, such as the quality of light in the growth rooms with LED lamps, the adjustment of the sugar content in the culture medium and the use of ventilation of the recipients (Pawłowska et al., 2018; Batista et al., 2018). These provide a more favorable environment for the development of plants in vitro, for the production of photoassimilates, and also as a stimulus perceived by photoreceptors that trigger photomorphogenesis in plants (Gupta \& Karmakar, 2017).

Considering the importance that the genus Corymbia and its hybrids currently represent for the forestry sector, the present study aimed to evaluate the effect of photomyxotrophism (light quality, sucrose concentration and forms of sealing) on the in vitro elongation of one clone's microcuttings of a hybrid of Corymbia citriodora $\times$ C. torelliana and three of C. torelliana $\times$ C. citriodora.

\section{MATERIAL AND METHODS}

\section{Study location and experimental material}

The experiments were conducted at the Tissue Culture Laboratory II of the Institute of Biotechnology Applied to Agriculture (BIOAGRO) at the Federal University of Viçosa - UFV, Viçosa / MG. The genetic material used to obtain the explants came from ministumps of a hybrid clone of Corymbia citriodora $\times$ C. torelliana (CT01) and three from C. torelliana $\times$ C. citriodora (TC01, TC02 and TC03), from the company CMPC - Celulose Riograndense, located in the municipality of Guaíba / RS.

For the elongation phase, the shoots produced in the in vitro multiplication phase were prepared by isolating four standardized $0.5 \mathrm{~cm}$ shoots and inoculated under aseptic conditions, in glass flasks ( $250 \mathrm{~mL}$ capacity), grown for 35 days, containing $50 \mathrm{ml}$ of JADS medium (Correia et al., 1995), to which were added: $100 \mathrm{mg} \mathrm{L}^{-1}$ of myoinositol, $800 \mathrm{mg} \mathrm{L}^{-1}$ of PVP-30 (polyvinylpyrrolidone - Vetec $®$ ), $6 \mathrm{~g} \mathrm{~L}^{-1}$ of agar, $0.05 \mathrm{mg} \mathrm{L}^{-1}$ of BA (6-benzyladenine Sigma Co.) and $0.25 \mathrm{mg} \mathrm{L}^{-1}$ of 3-indolbutyric acid (IBA) (Sigma ${ }^{\circledR}$ ).

The culture media were prepared by using deionized water and the $\mathrm{pH}$ adjusted to $5.8 \pm$ 0.05 with $\mathrm{NaOH}(0.1 \mathrm{M})$ and $\mathrm{HCl}(0.1 \mathrm{M})$, before autoclaving and adding the agar. The autoclaving of the culture medium was performed at a temperature of $121^{\circ} \mathrm{C}$ and a pressure of approximately $1 \mathrm{~kg} \mathrm{~cm}^{-2}$, for 20 minutes. The treatments were maintained in a growth room at $25 \pm 2{ }^{\circ} \mathrm{C}$ for a photoperiod of 16 hours of light and irradiance of $40 \mu \mathrm{mol} \mathrm{m}^{-2} \mathrm{~s}^{-1}$ (quantified by radiometer, LI-COR®, LI-250A Light Meter).

\section{Light quality}

To evaluate the effects of light quality on in vitro elongation, the experiment was arranged in a $4 \times 3$ factorial arrangement, in a completely randomized design, with four hybrid Corymbia 
clones (CT01, TC01, TC02 and TC03) and three light sources: Fluorescent lamp (F/L) (HO Sylvania T12, 110 W, São Paulo, SP, Brazil), White LED lamp (W/L) (SMD 100, 18 W, Vilux ${ }^{\circledR}$, Vitória, ES, Brazil) and LED lamp red/blue (R/B) (LabPARLL-HR / DB-480, 11.6 W, LabLumens ${ }^{\circledR}$, Carapicuíba, SP, Brazil), containing forty replications, composed of one explant each. At 35 days of cultivation, the length of shoots $(>0,5 \mathrm{~cm})$, the average number of shoots per explant $(>0.5 \mathrm{~cm})$; the oxidation and vigor according to a scale of notes, and the content of photosynthetic pigments were evaluated.

The light spectra were measured by a spectroradiometer (Ocean Optics Spectra-Suite, Ocean Optics, Dunedin, FL) (Figure 1).

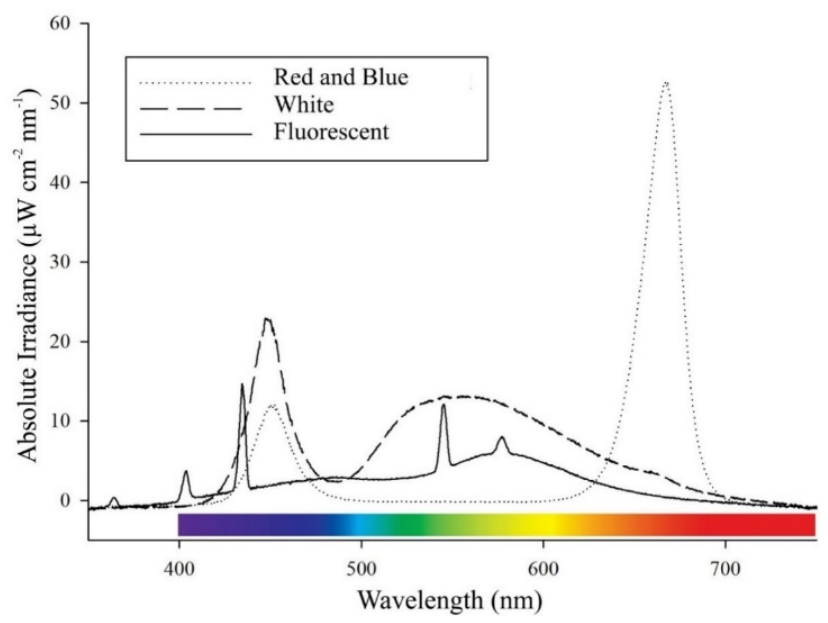

Figure 1. Variations in absolute irradiance $\left(\mu \mathrm{W} \mathrm{cm} \mathrm{cm}^{-1}\right)$ and wavelength $(\mathrm{nm})$ of light emitted by fluorescent lamps, white LEDs and red/blue LEDs used in the in vitro elongation experimentation of Corymbia hybrid clones (CT01, TC01, TC02 and TC03) obtained from the growth room of LCT II, BIOAGRO / UFV.

\section{Sucrose concentrations}

Based on the best results from the previous experiment, the red/blue LEDs light source was used for all the analyzed clones.

To test the different sucrose concentrations, the experiment was arranged in a $4 \times 3$ factorial arrangement, in a completely randomized design, with four hybrid Corymbia clones (CT01, TC01, TC02 and TC03) and three sucrose concentrations $\left(0,15\right.$ and $\left.30 \mathrm{~g} \mathrm{~L}^{-1}\right)$, containing forty repetitions, composed of one explant each. At 35 days of cultivation, the length of shoots $(>0.5 \mathrm{~cm})$, average number of shoots per explant $(>0.5 \mathrm{~cm})$, oxidation and vigor according to a scale of notes was evaluated.

\section{Sealing forms}

For the treatments that provided the best results of the previous experiment, for all analyzed clones, $15 \mathrm{~g} \mathrm{~L}^{-1}$ of sucrose was used in the culture medium.

The experiment was arranged in a $4 \times 2$ factorial arrangement, in a completely randomized design, with four Corymbia hybrid clones (CT01, TC01, TC02 and TC03) and two forms of sealing, characterized by rigid polypropylene caps without membrane (W/M); and polypropylene caps with two holes $\left(10 \mathrm{~mm}\right.$ ) covered with $0.45 \mu \mathrm{m}$ membranes (MilliSeal ${ }^{\circledR}$ AVS045 Air Vent) (2/M).

\section{Scale of notes: vigor and oxidation of explants}

Assessments of vigor and oxidation (Figure 2) were evaluated according to a scale of scores (Oliveira et al., 2016). 


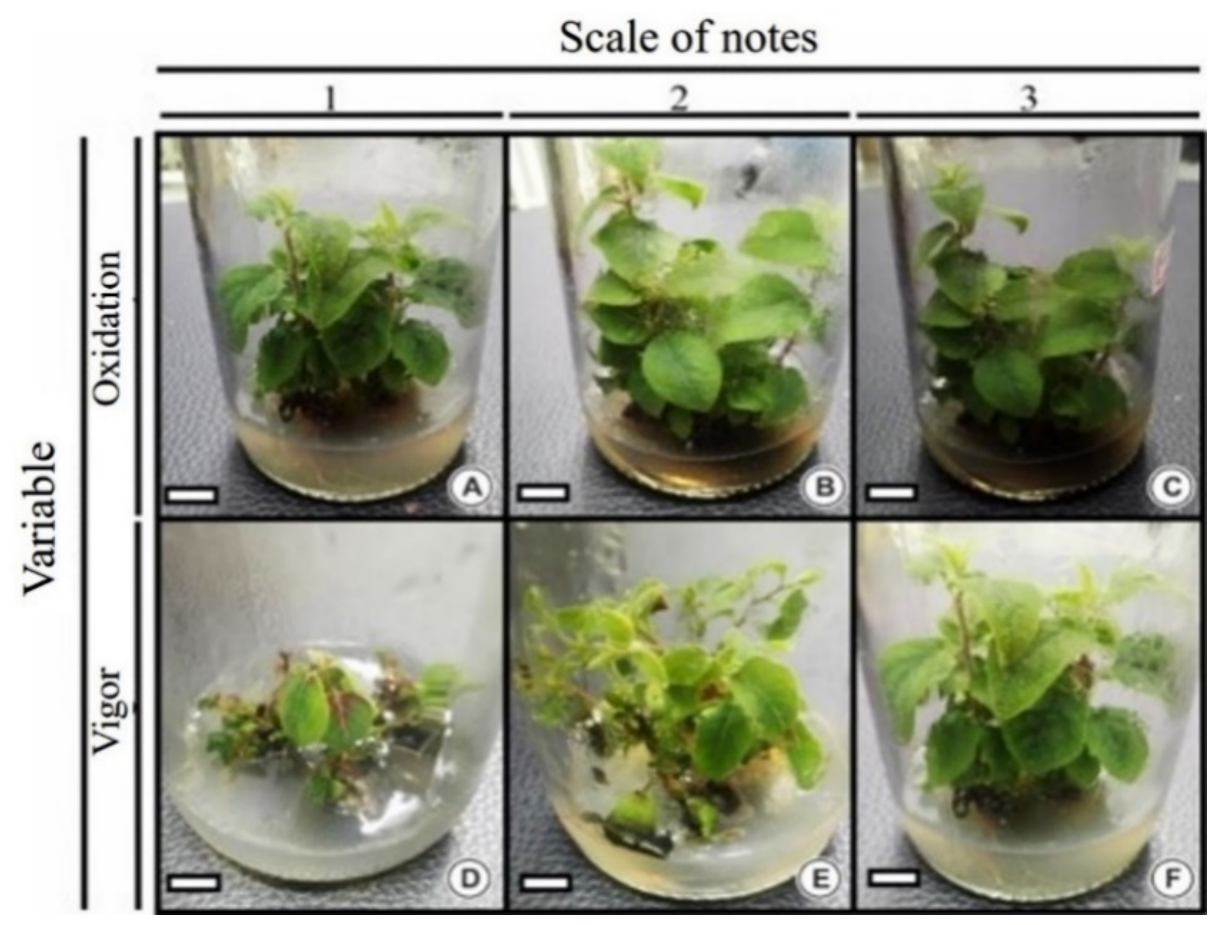

Figure 2. Oxidation and vigor evaluations according to a scale of notes. (A) 1 = Null: no oxidation;

(B) 2 = Medium: reduced oxidation at the base of the explants (grayish-tone culture medium;

(C) 3 = High: complete shoot oxidation (blackish-tone culture medium); (D) 1 = Low: no shoots

development and/or senescence and death; (E) 2 = Good: shoots with good growth but with small leaves; (F) 3 = Optimal: shoots with active growth without apparent nutritional deficiency. Bar $=1,0 \mathrm{~cm}$

\section{Analysis of photosynthetic pigments content}

Leaf discs ( $25 \mathrm{mg}$ of fresh leaf material) were sampled from shoots of the in vitro elongation, after 35 days under the different light qualities and inoculated in $5 \mathrm{~mL}$ of DMSO solution (Sigma Aldrich) saturated with calcium carbonate for 48 hours in the dark (Santos et al., 2008). The absorbance of the samples was determined in triplicate in a quartz cuvette with a $10 \mathrm{~mm}$ optical path, using a Genesys 10UV spectrophotometer (ThermoScientific, USA). The wavelengths (665, 649 and $480 \mathrm{~nm}$ ) and the equations for calculating the concentrations of chlorophylls $a, b$ and total carotenoids were based on the method described by Wellburn (1994).

\section{Data analysis}

The analyses were processed using R software, version 3.0.3 (R Core Team, 2018), with the aid of the ExpDes package, version 1.1.2 (Ferreira et al., 2013). The treatment averages were used to perform the statistical analyses. The data of the variables that did not present a normal distribution according to the Shapiro-Wilk test at 5\% significance were transformed into arcsen. For the significant variables, the Tukey test was performed at 5\% significance level.

\section{RESULTS}

\section{Effect of light quality on in vitro elongation}

The different light qualities used in the in vitro elongation of Corymbia hybrid clones, influenced the average length of the shoots and vigor of the explants at 35 days after inoculation (Figure 3), but without significant interaction between the factors $(p>0.05)$. The highest average of shoot lengths and vigor was found for clone TC03 $(4.54 \mathrm{~cm}$ and 2.83$)$, differing statistically $(p<0.05)$ for TC01 and TC02, respectively (Figure 3A and 3E). In view of the 

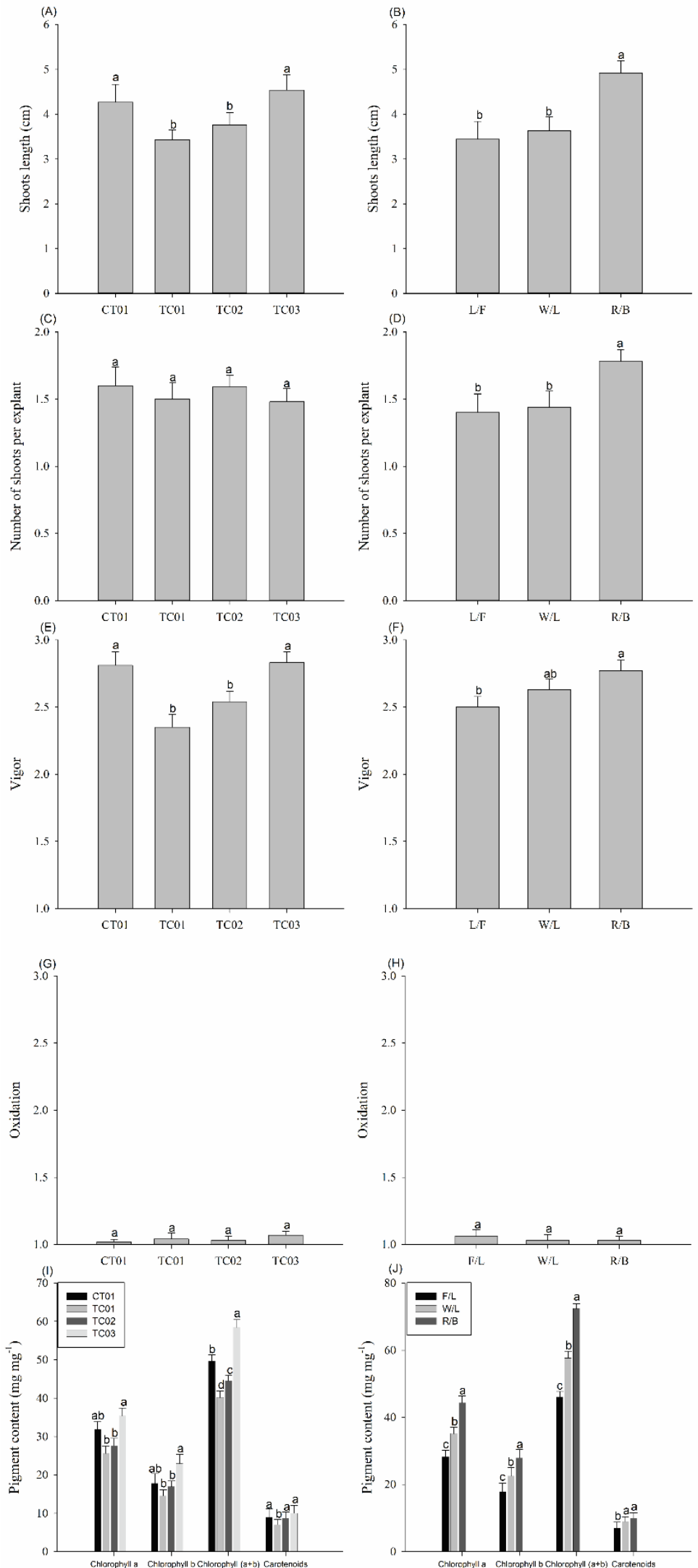

Figure 3. Characteristics observed at 35 days in vitro elongation. (A) Length of shoots per explant as a function of hybrid clones; (B) Length of shoots per explant as a function of different light qualities; (C) Number of shoots per explant as a function of hybrid clones; (D) Number of shoots per explant as a function of different light qualities; (E) Vigor of shoots as a function of hybrid clones; F) Vigor of shoots according to different light qualities; (G) Oxidation of shoots as a function of hybrid clones; H) Oxidation of shoots as a function of different light qualities; I) Content of photosynthetic pigments as a function of hybrid clones; J) Content of photosynthetic pigments as a function of different light qualities * Means followed by the same letter do not differ from each other by the Tukey test at 5\% probability. Bars represent sample standard deviation. 
number of shoots and oxidation, clone CT01 (on average 1.60 and 1.03) showed the best results, but did not differ between the genotypes used (Figure $3 \mathrm{C}$ and Figure 3G). Regarding the content of photosynthetic pigments (chlorophyll $a, b$ and carotenoids) the results show that the TC03 clone had the highest amounts (Figure 31).

Regarding the quality of light, the treatment with R/B stood out for all the characteristics evaluated (length of shoots, number of shoots, vigor of explants and photosynthetic pigments content), presenting the best morphological responses in in vitro culture (Figure 3B, 3D, $3 \mathrm{~F}$ and $3 \mathrm{~J})$.

\section{Effect of sucrose concentration on in vitro elongation}

For the characteristics studied, a difference in response was observed between Corymbia clones and sucrose concentrations used in in vitro elongation, at 35 days of culture (Figure 4), but without significant interaction between factors $(p>0.05)$.

The length of the shoots and the vigor of the explants showed a similar behavior, with the highest averages being verified with clone TC03 $(5.02 \mathrm{~cm}$ and 2.77), differing statistically $(p<0.05)$ for clones TC01 and TC02 (Figures 4A, 4E). As for the number of shoots and oxidation of explants, the CT01 clone stood out (on average 1.55 and 1.03) (Figure $4 \mathrm{C}$ and $4 G)$.

According to the sucrose concentrations used in the shoots length, number of shoots and explant vigor characteristics, it was observed that treatments 15 and $30 \mathrm{~g} \mathrm{~L}^{-1}$ were considered essential for in vitroelongation, with significant difference $(p<0,05)$ for treatment with $0 \mathrm{~g} \mathrm{~L}^{-1}$ of sucrose (Figure 4B, 4D and $4 \mathrm{~F}$ ). For the oxidation of the explants, the lowest values obtained were the ones treated with $0 \mathrm{~g} \mathrm{~L}^{-1}$ of sucrose, but did not differ statistically $(p>0.05)$ from the others (Figure $4 \mathrm{H}$ ).

\section{Effect of sealing forms on in vitro elongation}

The treatments involving the different clones and forms of sealing were presented independently $(p>0,05)$. The TC03 clone showed the highest average for the length of shoots $(4.87 \mathrm{~cm})$, differing statistically for the other treatments (Figure $5 \mathrm{~A}$ ). For the vigor of the explants (on average: 2.88), a similar behavior was observed, but there was only a significant difference for clone TC01 (Figure 5E).

For the number of shoots per explant, the best results were compared to clone CT01 (on average: 1.35) and TC02 (on average: 1.34), with a significant difference $(p<0.05)$ for TC01 and TC03 (Figure 5C). As for oxidation of explants, clone CT01 yielded the lowest average $(1,03)$; however, there was no difference between treatments $(p>0.05)$ (Figure $5 \mathrm{G}$ ).

Regarding the different forms of sealing used, the treatment with W/M provided the best results for the length of shoots and vigor of explants, with a significant difference $(p<0.05)$ for $2 / \mathrm{M}$ (Figure 5B and 5F), showing tissue growth with no nutritional deficiency, according to the scale of notes. There was no statistical difference for the oxidation of explants $(p>0.05)$ between treatments (Figure $5 \mathrm{H}$ ). In view of the number of shoots, he observed higher averages in treatment 2/M, differing from W/M (Figure 5D). 

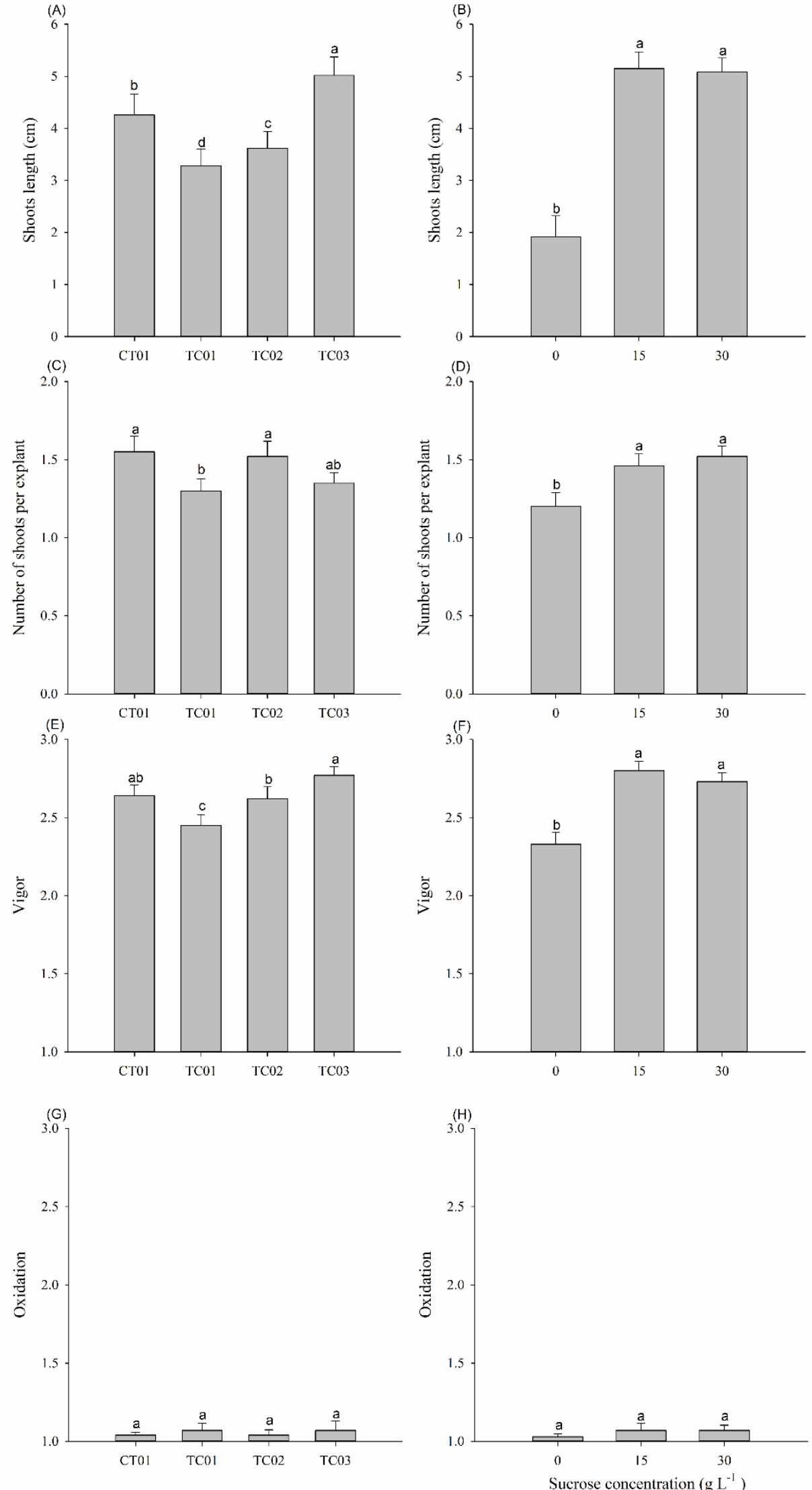

Figure 4. Characteristics observed at 35 days in vitro elongation. (A) Length of shoots per explant as a function of hybrid clones; (B) Length of shoots per explant as a function of different sucrose concentrations; (C) Number of shoots per explant as a function of hybrid clones; (D) Number of shoots per explant as a function of different sucrose concentrations; (E) Vigor of shoots as a function of hybrid clones; (F) Vigor of shoots related to different sucrose concentrations; (G) Oxidation of shoots for hybrid clones; (H) Oxidation of shoots per different sucrose concentrations * Means followed by the same letter do not differ from each other by the Tukey test at $5 \%$ probability. Bars represent sample standard deviation. 

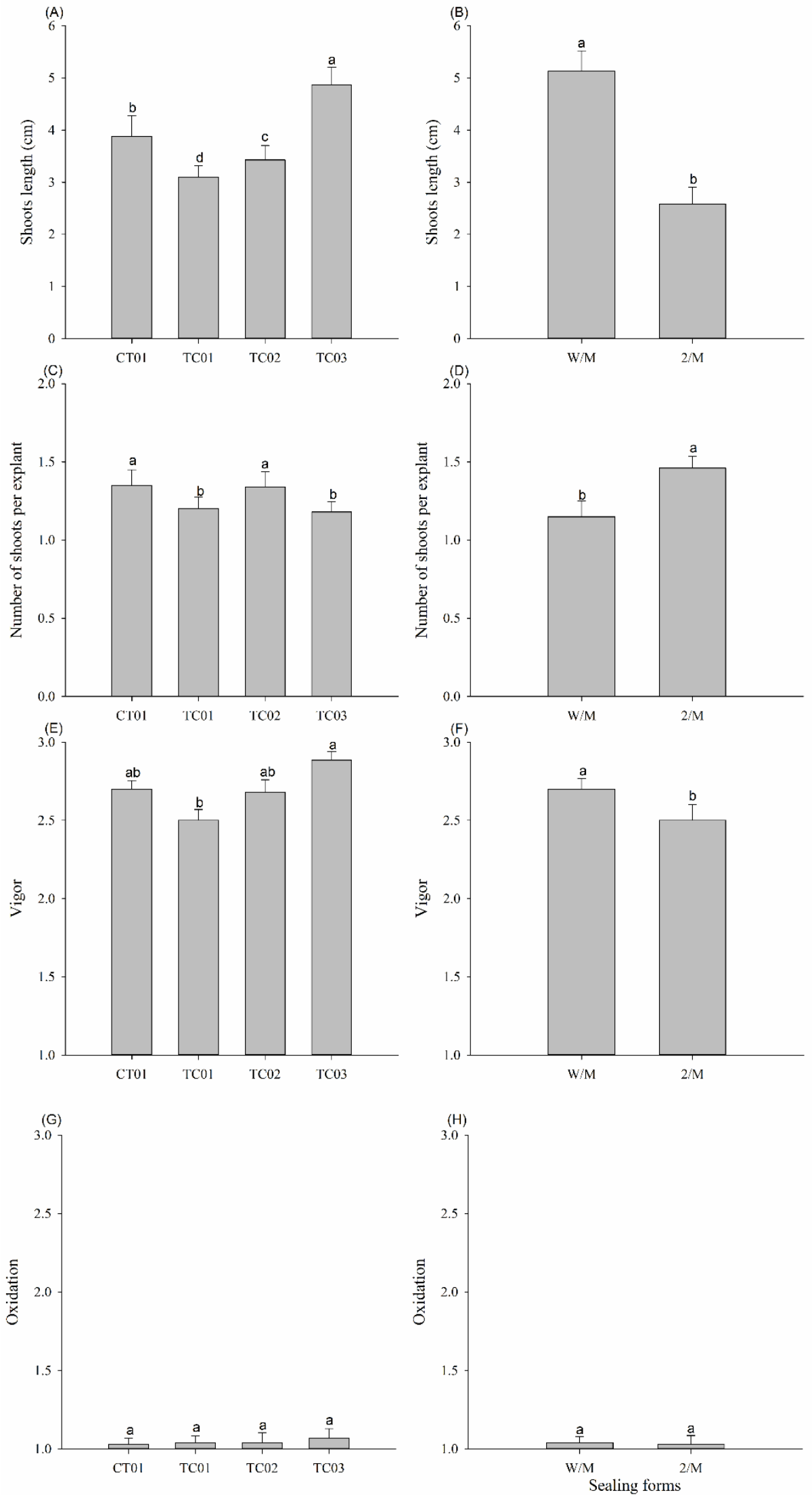

Figure 5. Characteristics observed at 35 days in vitro elongation. (A) Length of shoots per explant for hybrid clones; (B) Length of shoots per explant related to different sealing forms; (C) Number of shoots per explant according to hybrid clones; (D) Number of shoots per explant for different sealing forms; (E) Vigor of shoots by hybrid clones; (F) Vigor of shoots according to different sealing forms; (G) Oxidation of shoots in different hybrid clones; (H) Oxidation of shoots due to different sealing forms. * Means followed by the same letter do not differ from each other by Tukey's test at 5\% probability. Bars represent sample standard deviation. 


\section{DISCUSSION}

\section{Effect of light quality on in vitro elongation}

The light source used in the in vitro elongation of the explants influenced the growth of Corymbia hybrid clones, although there were variations in responses. Genotypic differences in in vitro development are reported in different species of the genus Corymbia, as observed for C. torelliana $\times$ C. citriodora (Souza et al., 2018), C. citriodora (Brondani et al., 2018) and C. citriodora $\times$ C. torelliana (Arya et al., 2009).

The use of red/blue LEDs influences the morphogenesis of several plant species grown in vitro (Batista et al., 2018). Results have shown that LED light is more suitable for plant development, however, responses may vary according to plant species. One cause for this differentiation is related to the regulation of physiological processes, such as photomorphogenesis, resulting in the highest quality, production and development of micropropagated seedlings (Gupta \& Karmakar, 2017).

Data described in the literature corroborate those found in this study, since the combination of red/blue LEDs in Populus euramericana Moench (pro sp.) induced greater length, number, pigment content and quality of shoots (Kwon et al., 2015). The biosynthesis of chlorophyll a, b and carotenoids is influenced by the quality of light emitted, presenting greater efficiency in the photosynthetic process predominantly in the combined blue and red wavelengths (Gupta \& Karmakar, 2017). Batista et al. (2018) confirmed the superiority of LED lamps in the in vitro development of plants when compared to fluorescent lamps.

\section{Effect of sucrose concentration on in vitro elongation}

The sucrose concentration had a direct implication on the elongation of Corymbia clones, mainly considering $15 \mathrm{~g} \mathrm{~L}^{-1}$, in which there is a reduction of this component in the medium; since the usual concentration in Corymbia micropropagation is $30 \mathrm{~g} \mathrm{~L}^{-1}$. Studies report the use of $30 \mathrm{~g} \mathrm{~L}^{-1}$ of sucrose in the micropropagation process, being responsible for the multiplication or elongation (Arya et al., 2009; Brondani et al., 2018; Souza et al., 2018).

Costa et al. (2017), working with Ochroma pyramidale (Cav. ex Lam), found the highest averages for the length of shoots using the concentration of $15 \mathrm{~g} \mathrm{~L}^{-1}$ of sucrose. Silva et al. (2018) report its positive effect on different species, which benefits cultivation and reduces costs.

With the exclusion of the carbon source in the medium, Monfort et al. (2015) working with Ocimum selloi Benth, found a negative effect on the number, length and dry matter of shoots. In in vitro cultivation, plants partially lose autotrophism and, consequently, need an exogenous source of carbohydrates, with sucrose being the most used in plant tissue culture (Shahina \& Anwar, 2014).

\section{Effect of sealing forms on in vitro elongation}

The use of the membraneless system had a direct implication in the in vitro elongation of Corymbia clones. The amount of $\mathrm{CO}_{2}$ assimilated by the plant in in vitro propagation will depend on the genotype, resulting in plant development (Tisarum et al., 2018).

Results similar to the study were found in Eucalyptus grandis W. Will ex Maiden $\times$ Eucalyptus urophylla S.T. Blake, with greater length and quality of shoots in the system without air injection in temporary immersion bioreactors (Oliveira et al., 2014). In contrast, two varieties of Capsicum annuum (L.) Kuntze Batista et al. (2017) found greater length of the aerial part and number of leaves per explant in a membrane system, when compared to the conventional system.

In vitro conditions are stressful for plant growth and high $\mathrm{CO}_{2}$ concentrations are a major cause of oxidation and reduced vigor during in vitro cultivation (Tisarum et al., 2018). Studies have reported various effects on plants grown in vitro without the use of a membrane, such as improved growth and increased content of photosynthetic pigments, mainly by maintaining 
adequate $\mathrm{CO}_{2}$ concentrations to stimulate photosynthesis (Hoang et al., 2017). However, the use of systems that increase the supply of $\mathrm{CO}_{2}$ for some species in vitro, promotes the development of the photosynthetic apparatus, resulting in a higher rate of multiplication and acclimatization of seedlings to ex vitro conditions (Shin et al., 2014).

\section{CONCLUSIONS}

1) The red/blue LED light source proved to be the most suitable, with the best results for shoots length, number of shoots per explant, vigor, oxidation and photosynthetic pigment content of the microcuttings;

2) Sucrose significantly influenced the performance of in vitro culture, with a reduction to $15 \mathrm{~g} \mathrm{~L}^{-1}$ giving the best results in view of the variables analyzed;

3) The use of flasks without membranes is effective on elongating microcuttings in vitro;

4) Clones СТ01 and TC03 showed the best results in view of the evaluated characteristics, being promising for seedling production in vitro.

\section{ACKNOWLEDGMENTS}

CNPq (National Council for Scientific and Technological Development, Brazil), FAPEMIG (Minas Gerais State Research Support Foundation) and CAPES (Coordination for the Improvement of Higher Education Personnel) for financial support. BIOAGRO (Institute of Biotechnology Applied to Agriculture) for supplying the laboratory with infrastructure. CMPC (Celulose Riograndense) for genetic material (clones) and financial support.

\section{REFERENCES}

Arya, I. D., Sharma, S., Chauhan, S., \& Arya, S. (2009). Micropropagation of superior eucalyptus hybrids FRI-5 (Eucalyptus camaldulensis Dehn $\times$ E. tereticornis Sm) and FRI-14 (Eucalyptus torelliana F.V. Muell×C. citriodoraHook): a commercial multiplication and field evaluation. African Journal of Biotechnology, 8(21), 5718-5726. http://dx.doi.org/10.5897/AJB09.822.

Assis, T. F. (2014). Melhoramento genético de Eucalyptus: desafios e perspectivas. In Anais do $3^{\circ}$ Encontro Brasileiro de Silvicultura (pp. 127-148). Jataí: UFJ.

Batista, D. S., Dias, L. L. C., Rêgo, M. M., Saldanha, C. W., \& Otoni, W. C. (2017). Flask sealing on in vitro seed germination and morphogenesis of two types of ornamental pepper explants. Ciência Rural, 47(3), 1-6. http://dx.doi.org/10.1590/0103-8478cr20150245.

Batista, D. S., Felipe, S. H. S., Silva, T. D., de Castro, K. M., Mamedes-Rodrigues, T. C., Miranda, N. A., RíosRíos, A. M., Faria, D. V., Fortini, E. A., Chagas, K., Torres-Silva, G., Xavier, A., Arencibia, A. D., \& Otoni, W. C. (2018). Light quality in planttissueculture: does it matter? In Vitro Cellular \& Developmental Biology. Plant, 54(3), 195-215. http://dx.doi.org/10.1007/s11627-018-9902-5.

Brondani, G. E., Oliveira, L. S., Konzen, E. R., Silva, A. L. L. D., \& Costa, J. L. (2018). Mini-incubators improve the adventitious rooting performance of Corymbiaand Eucalyptus microcuttings according to the environment in which they are conditioned. Anais da Academia Brasileira de Ciências, 90(2, Suppl.1), 2409-2423. PMid:29044323. http://dx.doi.org/10.1590/0001-3765201720170284.

Correia, A. D., Gonçalves, A. N., Couto, H. Z., \& Ribeiro, M. C. (1995). Efeito do meio de cultura líquido e sólido no desenvolvimento de gemas de Eucalyptus grandis $\times$ Eucalyptus urophyllana multiplicação in vitro. IPEF, 48-49, 107-116.

Costa, M. B. T., Arruda, A. S., Vieira, M. C., Paula, M. S. P., \& Luz, J. M. Q. (2017). Estabelecimento in vitro de Ochromapyramidaleem diferentes concentrações de meio MS e sacarose. Revista Agrotecnologia, 8(1), 1-9. http://dx.doi.org/10.12971/agrotec.v8i1.5252.

Ferreira, E.B., Cavalcanti, P.P., \& Nogueira, D.A. (2013). ExpDes: Experimental Designs package. $R$ packageversion 1.1.2. Viena: CRAM/R Foundation for Statistical Computing.

Gupta, S. D., \& Karmakar, D. (2017). Machine vision based evaluation of impact of light emitting diodes (LEDs) on shoot regeneration and the effect of spectral quality on phenolic content and antioxidant capacity in Swertiachirata. Journal of Photochemistry and Photobiology, 174, 162-172. http://dx.doi.org/10.1016/j.jphotobiol.2017.07.029.

Hoang, N. N., Kitaya, Y., Morishita, T., Endo, R., \& Shibuya, T. (2017). A comparative study on growth and morphology of wasabi plantlets under the influence of the micro-environment in shoot and root 
zones during photoautotrophic and photomixotrophic micropropagation. Plant Cell, Tissue and Organ Culture, 130(2), 255-263. http://dx.doi.org/10.1007/s11240-017-1219-2.

Kwon, A. R., Cui, H. Y., Lee, H., Shin, H., Kang, K. S., \& Park, S. Y. (2015). Light quality affects shoot regeneration, cell division, and Wood formation in elite clones of Populus euramericana. Acta Physiologiae Plantarum, 37(3), 65-74. http://dx.doi.org/10.1007/s11738-015-1812-0.

Monfort, L. E. F., Pinto, J. E. B. P., Bertolucci, S. K. V., Rossi, Z. T. T., Lima, A. F., Silva, S. T., \& Silva, G. M. (2015). Micropropagação e germinação de sementes in vitro de atroveran. Revista Ceres, 62(2), 215223. http://dx.doi.org/10.1590/0034-737X201562020012.

Oliveira, L. S., Xavier, A., Lopes, A. P., Takahashi, E. K., \& Otoni, W. C. (2016). Multiplicação e alongamento in vitro de clones híbridos de Eucalyptus globulus. Ciência Florestal, 26(1), 235-247. http://dx.doi.org/10.5902/1980509821524.

Oliveira, M. L., Xavier, A., Penchel Filho, R. M., \& Reis, J. P. (2014). Efeito do intervalo de imersão e de injeção de ar na multiplicação in vitro de Eucalyptus grandis×Eucalyptus urophyllaem biorreator de imersão temporária. Ciência Florestal, 24(103), 37-45.

Pawłowska, B., Żupnik, M., Szewczyk-Taranek, B., \& Cioć, M. (2018). Impact of LED light sources on morphogenesis and levels of photosynthetic pigments in Gerbera jamesoniigrown in vitro. Horticulture, Environment and Biotechnology, 59(1), 115-123. http://dx.doi.org/10.1007/s13580-0180012-4.

R Core Team. (2018). R: A language and environment for statistical computing. Vienna, Austria: $\mathrm{R}$ Foundation for Statistical Computing.

Santos, P. R., Cruz, A. C. F., larema, L., Kuki, K. N., \& Otoni, W. C. (2008). Protocolo para extração de pigmentos foliares em porta-enxertos de videira micropropagados. Revista Ceres, 55(4), 356-364.

Shahina, P., \& Anwar, S. (2014). Factors affecting in vitro plant regeneration from cotyledonary node explant of Senna sophera(L.) Roxb. - A highly medicinal legume. African Journal of Biotechnology, 13(3), 413-422. http://dx.doi.org/10.5897/AJB2013.13126.

Shin, K. S., Park, S. Y., \& Paek, K. Y. (2014). Physiological and biochemical changes during acclimatization in a Doritaenopsis hybrid cultivated in different microenvironments in vitro. Environmental and Experimental Botany, 100, 26-33. http://dx.doi.org/10.1016/j.envexpbot.2013.12.004.

Silva, J. A. T., Pacholczak, A., \& Ilczuk, A. (2018). Smoke tree (Cotinus coggygriaScop.) propagation and biotechnology: A mini-review. South African Journal of Botany, 114, 232-240. http://dx.doi.org/10.1016/j.sajb.2017.11.009.

Souza, D. M. S. C., Xavier, A., Otoni, W. C., Miranda, N. A., \& Maggioni, J. H. (2018). Light quality in the in vitro introduction of Corymbiahybrid clones. Revista Árvore, 42(6), 1-9. http://dx.doi.org/10.1590/1806-90882018000600004.

Tisarum, R., Samphumphung, T., Theerawitaya, C., Prommee, W., \& Cha-um, S. (2018). In vitro photoautotrophic acclimatization direct transplantation and ex vitro adaptation of rubber tree (Heveabrasiliensis). Plant Cell, Tissue and Organ Culture, 133(2), 215-230. http://dx.doi.org/10.1007/s11240-017-1374-5.

Trueman, S. J., Hung, C. D., \& Wendling, I. (2018). Tissue culture of Corymbia and Eucalyptus. Forests, 9(2), 1-42. http://dx.doi.org/10.3390/f9020084.

Wellburn, A. R. (1994). The spectral determination of chlorophylls a and b, as well as total carotenoids, using various solvents with spectrophotometers of different resolution. Journal of Plant Physiology, 144(3), 307-313. http://dx.doi.org/10.1016/S0176-1617(11)81192-2.

Wendling, I., Trueman, S. J., \& Xavier, A. (2014). Maturation and related aspects in clonal forestry - part I: concepts, regulation and consequences of phase change. New Forests, 45(4), 449-471. http://dx.doi.org/10.1007/s11056-014-9421-0.

Author's contributions: DMSCS: conceptualization, data curation, formal analysis, methodology, writing - original draft, writing - review \& editing; AX: supervision, validation, visualization; NAM: conceptualization, data curation, formal analysis, methodology, writing - original draft, writing - review \& editing; RG: formal analysis, methodology, writing - original draft; GAS: supervision, validation, visualization; BMRTV: resources, visualization; WCO: supervision, validation, visualization. 